\title{
XYLANASE PRODUCTION BY ASPERGILLUS AWAMORI UNDER SOLID STATE FERMENTATION CONDITIONS ON TOMATO POMACE
}

\author{
Marcelo A. Umsza-Guez ${ }^{1}$ *, Ana B. Díaz ${ }^{2}$, Ignacio de Ory ${ }^{2}$, Ana Blandino ${ }^{2}$, Eleni Gomes ${ }^{1}$, Ildefonso Caro ${ }^{2}$ \\ ${ }^{1}$ Laboratório de Bioquímica e Microbiologia Aplicada, Instituto de Biociências, Letras e Ciências Exatas, Universidade Estadual \\ Paulista, São José do Rio Preto, SP, Brazil; ${ }^{2}$ Departamento de Ingeniería Química y Tecnología de Alimentos, Facultad de \\ Ciencias, Universidad de Cádiz, Campus Río San Pedro, Apdo. 40, Puerto Real, Cádiz 11510, Spain.
}

Submitted: May 27, 2010; Approved: June 06, 2011.

\begin{abstract}
In this work, tomato pomace, a waste abundantly available in the Mediterranean and other temperate climates agro-food industries, has been used as raw material for the production of some hydrolytic enzymes, including xylanase, exo-polygalacturonase (exo-PG), cellulase (CMCase) and $\alpha$-amylase. The principal step of the process is the solid state fermentation (SSF) of this residue by Aspergillus awamori. In several laboratory experiments, maximum xylanase and exo-PG activities were measured during the first days of culture, reaching values around 100 and $80 \mathrm{IU} / \mathrm{gds}$ (international units of enzyme activity per gram of dried solid), respectively. For CMCase and $\alpha$-amylase production remained almost constant along fermentation, with average values of 19 and $21.5 \mathrm{IU} / \mathrm{gds}$, respectively. Experiments carried out in a plate-type bioreactor at lab scale showed a clear positive effect of aeration on xylanase and CMCase, while the opposite was observed for exo-PG and $\alpha$-amylase. In general, xylanase was the enzyme produced in higher levels, thus the optimum conditions for the determination of the enzyme activity was characterized. The xylanase activity shows an optimum $\mathrm{pH}$ of 5 and an optimum temperature of $50{ }^{\circ} \mathrm{C}$. The enzyme is activated by $\mathrm{Mg}^{2+}$, but strongly inhibited by $\mathrm{Hg}^{2+}$ and $\mathrm{Cu}^{2+}$. The enzymatic activity remains quite high if the extract is preserved in a range of $\mathrm{pH}$ from 3 to 10 and a temperature between $30^{\circ} \mathrm{C}$ to $40^{\circ} \mathrm{C}$.
\end{abstract}

Key words: Solid state fermentation (SSF); tomato pomace; hydrolytic enzymes; plate-type bioreactor; xylanase production.

\section{INTRODUCTION}

Tomato (Lycopersicon esculentum) is one of the most widely consumed fresh vegetables in the industrialized world, especially in the Mediterranean agri-food industry. It is also widely used by food industries as a raw material for the production of derived products such as tomato juice, paste, puree, ketchup, sauce and salsa (18). The world and Brazil production of tomato in 2008 were 130 and near 4 million tonnes respectively (23). These quantities correspond to $3 \%$ of

*Corresponding Author. Mailing address: Laboratório de Bioquímica e Microbiologia Aplicada. Instituto de Biociências, Letras e Ciências Exatas (IBILCE). Universidade Estadual Paulista (UNESP). São José do Rio Preto - SP, Cristóvão Colombo, 2265, CEP 15054-000 (BRAZIL).; E-mail: paraumsza@hotmail.com 
the world production, a figure that has been maintained during recent years. Tomato processing plants produce annually large amounts of a by-product known as tomato pomace, which represents $4 \%$ of the initial fruit weight. This residue consists of tomato peels, seeds and some pulp (24). Although the skin is a raw material for pigments production, such as lycopene and the seeds contain food-use lipids, this product is given away freely to be used as feedstuffs by local farmers (2). In fact, the texture and protein content of this material (30-40\%) makes it very attractive to the feedstuffs industry. On the other hand, the lability of the wet material compared to the stability of the dried one recommends a drying stage which increases the usage costs.

In addition to the above mentioned components, the tomato fruit cell wall is composed of three major polysaccharides, pectin, hemicelluloses and cellulose (26). The hemicellulosic fraction includes xyloglucans, glucomannans and galactomannans which are covalently linked to pectin and hydrogen-bonded to cellulose $(49,22)$. In this sense, xylans and xyloglucans are the major components of plant hemicelluloses and the second most abundant renewable polysaccharide after cellulose (37). Xylan is an heterogeneous polysaccharide consisting of $\beta$-1,4-linked D-xylosyl residues on the back bone, but also contains arabinose, glucuronic acid and arabinoglucuronic acids linked to the D-xylose back bone. Considering the complexity of the molecular structure, xylan requires two different enzyme activities for hydrolysis. These are xylanase or endoxylanase (1,4- $\beta$-D-xylan xylanohydrolase, E.C. 3.2.1.8) and $\beta$-xylosidase (1,4-D- $\beta$-xylan xylohydrolase, E.C. 3.2.1.37), which are responsible of the hydrolysis of main chain, the former attacking the internal main-chain linkages and the latter releasing xylosyl residues by endwise attack of xylooligosaccharides (54). Related to this, it has been found that the general enzymatic activity on the fruit grows significantly during certain phases of the ripening period (9).

Xylanases or endoxylanases are used in several industrial processes such as the conversion of xylan into xylose (10), pulp and paper industries for bleaching kraft pulp (17), juices clarification, extraction of coffee, plant oils and starch (51), bioconversion of lignocellulosic waste into their constituent sugars (44), improvement of the digestibility of animal feed, etc. (48). Xylanases constitute the major commercial proportion of hemicellulases and have a world-wide market of around 200 million dollars. The sales trends are expected to increase owing to the fact that these enzymes have attracted increasing attention for their potential use in several new applications: coffee extraction, preparation of soluble coffee, protoplastation of plant cells, and production of alkyl glycosides for use as surfactants and washing of precision devices and semiconductors (5). Microbial xylanases are induced mainly by xylans, which makes the cost of the enzyme production high. Therefore, the use of abundant and low cost agricultural byproducts as substrates of fermentation for the production of xylanases is one of the ways to substantially reduce the enzyme production cost.

Among existing technologies in the fermentation industry, solid state fermentation (SSF) shows many advantages over fermentation in submerged culture, such as lower cost and much lower reactor volumes $(39,42)$. Additionally, this cultivation technique permits the use of different agricultural and agro-industrial residues as substrates such as wheat bran and soy bran $(12,16)$, sugar cane bagasse (1), lemon and orange peels $(27,47)$, etc. In this way, xylanolitic enzymes have been successfully produced in SSF using solid substrates such as corn cobs, rice bran, rice husk (6), sunflower head (40), grape pomace (19) or wheat bran (8).

For these reasons, considering that tomato pomace is a waste abundantly available and its chemical composition is quite complete, including proteins, lipids, carbohydrates, aminoacids, carotenoids and minerals (2), the first objective of this work was to evaluate the production of several hydrolytic enzymes of industrial applicability using this residue as a solid medium of fermentation. Specifically, the synthesis of xylanase, CMCase (a type of cellulase), $\alpha$-amylase and exo-PG 
(a type of pectinase) by Aspergillus awamori was analyzed. We chose this microorganism because it had shown a very good performance in enzymes production by SSF on other substrates $(11,21,33)$. In addition, a plate-type SSF bioreactor at lab scale was used in order to evaluate the effect of aeration on enzymes production. This type of bioreactor was selected for these experiments because its configuration allows the application of adjustable forced air flow and the distribution of the substrate along different layers of low bed height improves heat and mass transfer and these effects presumably encourages the development of the fermentative process $(34,46)$. Finally, due to xylanase was the enzyme produced in higher levels (see Results and Discussion section) and in order to ensure that the obtained data are reliable, a complete revision of the optimal conditions for the determination of the xylanase activity was performed. In this sense, the optimum working $\mathrm{pH}$ and temperature, the effect of metal ions and the stability against $\mathrm{pH}$ and temperature of this enzyme has been studied.

\section{MATERIALS AND METHODS}

\section{Microorganism and solid substrate}

An industrial strain of Aspergillus awamori 2B.361 U2/1 was originally obtained from ABM Chemicals, Woodley, Cheshire (30). The Commonwealth Mycological Institute classified the particular strain in the Aspergillus niger complex because it is a sequential mutant of NRRL 3312, which is a member of the A. niger series. Spores were propagated and stored on slants which contained a medium composed of $\left(\mathrm{g} \mathrm{L}^{-}\right.$ $\left.{ }^{1}\right)$ : 1 peptone, 0.5 yeast extract, 15 agar, 6 xylan and 1 pectin. This medium contained xylan and pectin as sole carbon sources to induce the production of some of the studied enzymes (xylanases and exo-polygalacturonases).

Fresh tomatoes were acquired in a local market and processed to simulate the agro-industrial waste. After tomato pressing, the raw material (peel, seeds and pulp) was abundantly washed with tap water, dried in an oven $\left(60^{\circ} \mathrm{C}\right.$ for $24 \mathrm{~h}$ ) and stored at room temperature until needed. Prior to use, the solid was milled and sieved, discarding particles smaller than $1 \mathrm{~mm}$ and greater than $3 \mathrm{~mm}$.

\section{Solid state fermentation and enzymes extraction}

Multiple solid state fermentations by $A$. awamori on tomato pomace were carried out in $250 \mathrm{~mL}$ conical flasks and in a plate-type SSF bioreactor, for evaluating the production of several hydrolytic enzymes in different conditions. For the first system, $5 \mathrm{~g}$ of dried and milled solid were sterilized in an autoclave $\left(120^{\circ} \mathrm{C}\right.$ and $1.2 \mathrm{~atm}$ for $\left.30 \mathrm{~min}\right)$ and inoculated with $4.5 \cdot 10^{7}$ spores/gds (spores per gram of dried solid). Next, the final moisture content of tomato pomace was adjusted to $70 \%$ $\mathrm{w} / \mathrm{w}$ by adding the required volume of a nutrient solution, constituted of $\left(\mathrm{g} \mathrm{L}^{-1}\right): 2.4$ urea, $9.8\left(\mathrm{NH}_{4}\right)_{2} \mathrm{SO}_{4}, 5.0 \mathrm{KH}_{2} \mathrm{PO}_{4}$, $0.001 \mathrm{FeSO}_{4} \cdot 7 \mathrm{H}_{2} \mathrm{O}, 0.0008 \mathrm{ZnSO}_{4} \cdot 7 \mathrm{H}_{2} \mathrm{O}, 0.004 \mathrm{MgSO}_{4} \cdot 7 \mathrm{H}_{2} \mathrm{O}$ and $0.001 \mathrm{CuSO}_{4} \cdot 5 \mathrm{H}_{2} \mathrm{O}$. The $\mathrm{pH}$ of this solution was adjusted to 5 with diluted $\mathrm{H}_{2} \mathrm{SO}_{4}$ prior to use. In all the experiments, pHs were measured with a standard $\mathrm{pH}$-meter with temperature compensation. This substrate preparation protocol was applied to ensure the homogeneity of the substrate richness in all the laboratory experiments, due to this factor influences the enzyme yield obtained. However this is not necessary in an industrial solid state fermentation process.

The flasks were plugged with cotton and incubated at 28 ${ }^{\circ} \mathrm{C}$ for 15 days. Every $24 \mathrm{~h}$, the whole fermented solid of several flasks were extracted with $40 \mathrm{~mL}$ of Tween $80(0.01 \%)$ per flask in a rotary shaker $\left(150 \mathrm{rpm}, 30 \mathrm{~min}, 4{ }^{\circ} \mathrm{C}\right)$. The suspension resulting after the extraction was centrifuged at $20,000 \mathrm{~g}$ for 10 minutes at $4{ }^{\circ} \mathrm{C}$, collecting the supernatant - the enzymatic extract- for its analysis. Conditions of extraction were optimized in a previous work (19). All experiments were made in triplicate. For characterization and stability experiments of xylanase, the enzymatic extracts were lyophilized and stored at $4{ }^{\circ} \mathrm{C}$ until its use.

\section{Plate-type SSF bioreactor}

A SSF plate-type bioreactor was constructed with five sterile $250 \mathrm{~mL}$ roux flasks (henceforth referred to as 'plates' 
for convenience) interconnected for aeration (Fig. 1). The reactor was connected to a filtered-air supply, entering sterile air into the first plate and leaving the reactor at the fifth plate after passing through the plates. The air flow was measured by a rotameter, passed through a humidification glass column and then was sterilized with a $0.45 \mu \mathrm{m}$ cellulose filter. The humidifier system consisted on a glass column filled with glass beads $(3 \mathrm{~mm})$ which were used to increase the hydraulic retention time of air into the water. Bioreactor was placed in a climate chamber which allowed fixing the external temperature to $28^{\circ} \mathrm{C}$.

To study the effect of aeration on xylanase production two different conditions were tested: aeration without humidification and water saturated aeration. For these experiments an average air flow rate of $120 \mathrm{~L} / \mathrm{h}$ was established. Temperature and humidity probes (Hygropalm,
Rotronic Inst. Corp., NY, USA) were fitted into the air phase above the solid substrate beds in the first and fifth plate, respectively, to check the evolution of both variables during fermentation. For fermentations, $10 \mathrm{~g}$ of inoculated tomato pomace $\left(4.510^{7}\right.$ spores/gds $)$ and later moistened to $70 \% \mathrm{w} / \mathrm{w}$ with the nutrient solution above mentioned were added to each plate. Bed height in each plate reached $1.3 \mathrm{~cm}$. Considering that the highest enzyme activities in conical flasks were obtained within the first 5 days (see Results and Discussion section), fermentations in the plate-type bioreactor were carried out at $28{ }^{\circ} \mathrm{C}$ for 5 days. After this fermentation period, the whole fermented solid of each plate was extracted with $80 \mathrm{~mL}$ of Tween $80(0.01 \%)$ and the supernatant obtained by centrifugation as indicated was used for the measurement of the xylanase activity. All the experiments were made in triplicate.

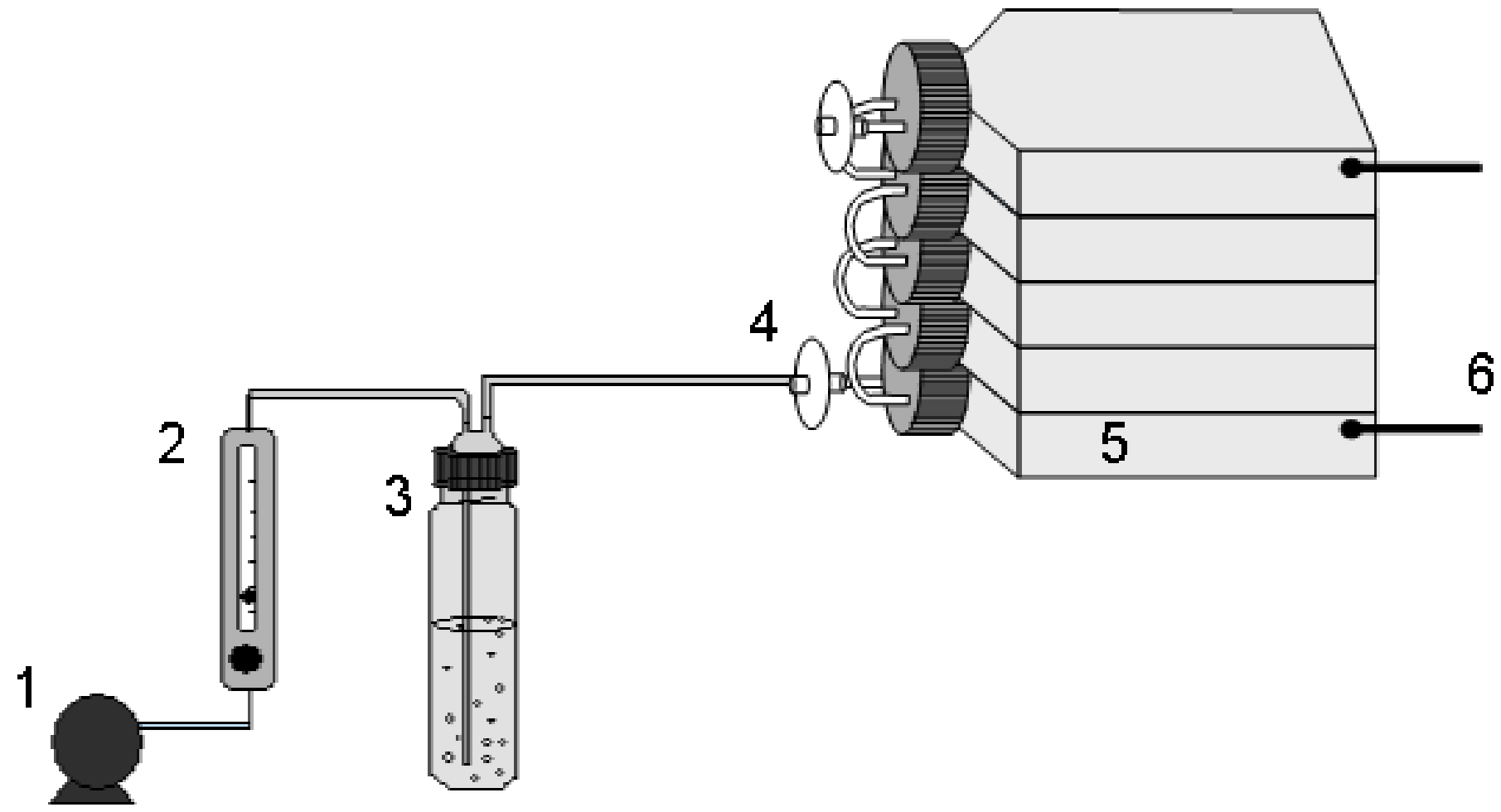

Figure 1. Plate-type bioreactor. 1. air pump; 2. rotameter; 3. humidification glass column; 4. air filter; 5. plates column; 6. temperature and humidity probes 


\section{Enzyme activity measurements}

The enzymatic activities of xylanase (EC 3.2.1.8), exopolygalacturonase (EC 3.2.1.67), $\alpha$-amylase (EC 3.2.1.1) and CMC-ase (EC 3.2.1.4) in the different extracts obtained after SSF were analysed. For xylanase, the reaction mixture containing $0.1 \mathrm{~mL}$ of enzymatic extract and $0.9 \mathrm{~mL}$ of xylan suspension $(0.5 \% \mathrm{w} / \mathrm{w}$ Birchwood xylan in $0.1 \mathrm{M}$ sodium acetate buffer, $\mathrm{pH} 5.0$ ) was incubated at $50{ }^{\circ} \mathrm{C}$ for $10 \mathrm{~min}$. CMC-ase activity was determined by the same procedure described for xylanase, but carboxymethyl-cellulose was used as substrate. The $\alpha$-amylase activity was assayed by adding 0.9 $\mathrm{mL}$ of soluble starch $(0.5 \% \mathrm{w} / \mathrm{v}$ in $0.25 \mathrm{M}$ acetate buffer, $\mathrm{pH}$ $5.0)$ to $0.1 \mathrm{~mL}$ of enzymatic extract. Exo-polygalacturonase (Exo-PG) activity was evaluated by adding $0.2 \mathrm{~mL}$ of enzymatic extract to $0.8 \mathrm{~mL}$ pectin solution $(0.5 \%$ pectin in $0.2 \mathrm{M}$ acetate buffer, $\mathrm{pH}$ 5.0). For the latter two enzymes, samples were incubated at $45^{\circ} \mathrm{C}$ for $10 \mathrm{~min}$. The $\mathrm{pH}$, temperature and time of incubation for each enzyme were selected according to the general recommendations of the literature $(11,20)$.

For all the enzymatic activity assays, the reducing groups released after the incubation period were measured by the 3,5dinitrosalicylic acid (DNS) method (36), using D-xylose, Dglucose or D-galacturonic acid as the standard depending on the type of enzyme analyzed, and calculated with the corresponding calibration curve. In all cases, an international unit of activity (IU) was defined as the amount of enzyme that produces $1 \mu \mathrm{mol}$ of reducing sugars per minute under the conditions used in the enzyme test. Enzymatic activities were expressed in international units per gram of dried solid (IU/gds) or per milliliter of extract (IU/mL) depending on the experiment.

In the case of the assay of reducing sugars present in the fermentation media, the DNS method was directly applied to the fresh enzymatic extracts, using D-glucose as the standard (36).

Because xylanase was the enzyme with best results (see
Results and Discussions section) and this would be the one with the greatest industrial potential, a comprehensive study of the influence of several factors on this enzymatic activity was developed. First, the influence of temperature, $\mathrm{pH}$, incubation time and presence of several cations was analyzed. Secondly, the influence of $\mathrm{pH}$ and temperature on the stability of this enzymatic activity during storage was studied.

\section{Influence factors on xylanase activity}

The lyophilized enzymatic extract $(0.1 \mathrm{~g})$, obtained after 5 days of SSF in conical flask as mentioned above, was resuspended in $50 \mathrm{~mL}$ of deionized water. This solution was used as the crude enzyme solution for the studies of influence factors and stability of xylanase activity. In these experiments, the enzyme activity was also measured following the standard protocol described above, but changing the parameter under study in each case.

Thus, in order to determine the $\mathrm{pH}$ influence on the xylanase activity, several buffers for the xylan solution was changed, according to the $\mathrm{pH}$ range tested, instead of the buffer pH 5.0 above mentioned. The following buffers were used ( 0.1 $\mathrm{M})$ : sodium acetate $(\mathrm{pH} 3.0-5.0)$, citrate-phosphate $(\mathrm{pH} 5.0$ 7.0), tris- $\mathrm{HCl}(\mathrm{pH} 7.0-8.5)$ and glycine- $\mathrm{NaOH}(\mathrm{pH} 8.5-11.0)$. Further, in the experiments performed to evaluate the influence of temperature, several incubation temperatures in the range of 25-80 ${ }^{\circ} \mathrm{C}$ were tested, by changing the preset temperature in the standard assay $\left(50^{\circ} \mathrm{C}\right)$. Moreover, the effect of incubation time was also studied by maintaining the crude enzyme solution in the absence of substrate at $50{ }^{\circ} \mathrm{C}$ for 6 hours. Periodically, an aliquot was withdrawn and placed on an ice bath, before being assayed for its residual xylanase activity at the standard conditions.

Finally, the effects of presence of different cations on xylanase activity was also determined. In this case, $100 \mu \mathrm{L}$ of the crude enzyme solution with $\mu 20 \mathrm{~L}$ of saline $0.1 \mathrm{M}$ sodium acetate buffer was incubated at $50{ }^{\circ} \mathrm{C}$ for 5 minutes. The saline $0.1 \mathrm{M}$ sodium acetate buffer is the standard $0.1 \mathrm{M}$ sodium 
acetate buffer ( $\mathrm{pH}$ 5.0), but containing one of the following salts in concentration $0.1 \mathrm{M}: \mathrm{FeSO}_{4},\left(\mathrm{NH}_{4}\right)_{2} \mathrm{SO}_{4}, \mathrm{MnSO}_{4}$, $\mathrm{K}_{2} \mathrm{SO}_{4}, \mathrm{MgSO}_{4}, \mathrm{KCl}, \mathrm{BaCl}_{2}, \mathrm{HgCl}_{2}, \mathrm{CaCl}_{2}$ or $\mathrm{CuCl}_{2}$. After incubation, residual activity was determined using the standard assay procedure previously described. The inhibition or activation degree of the enzyme activity was observed by comparing with a control sample containing the standard acetate buffer without salts, which was designed as the relative xylanase activity of $100 \%$.

\section{Stability of xylanase activity}

To establish the influence of the storage conditions of the enzymatic extract on the stability of the xylanase activity, the specific effect of $\mathrm{pH}$ and temperature was determined. First, for the $\mathrm{pH}$ study, lyophilized extract was dissolved with several buffer systems within the $\mathrm{pH}$ range of 3.0 to 10 (0.01 $\mathrm{g}$ of extract in $5 \mathrm{~mL}$ buffer), and incubated in the absence of substrate at $25{ }^{\circ} \mathrm{C}$ for $24 \mathrm{~h}$. After this time, the residual xylanase activity was measured at the standard conditions. The following buffer systems was used: sodium acetate $(\mathrm{pH} 3.0$ 5.0), citrate-phosphate $(\mathrm{pH}$ 5.0-7.0), tris- $\mathrm{HCl}(\mathrm{pH} 7.0-8.5)$ and glycine- $\mathrm{NaOH}(\mathrm{pH} 8.5-10.0)$.

Secondlly, the thermal stability of the enzyme was analyzed. Thermostability is the ability of the enzyme to resist against thermal unfolding in the absence of substrates. The values of this feature were determined by incubating the crude enzyme solution for $1 \mathrm{~h}$ in the absence of substrate, at six different temperatures in the range of study between 30 and 70 ${ }^{\circ} \mathrm{C}$. After incubation, the residual xylanase activity was determined at the standard conditions.

\section{RESULTS AND DISCUSSION}

\section{Enzymes production in conical flask}

Aspergillus awamori grown on tomato pomace, moistened to $70 \%$, produced significant quantities of xylanase and other hydrolytic enzymes such as exo-PG, CMCase and $\alpha$-amylase (see Figure 2A). In the case of xylanase, maximum activity values were reached between the $4^{\text {th }}$ and $8^{\text {th }}$ day of fermentation, remaining almost constant around $100 \mathrm{IU} / \mathrm{gds}$ during several days, and after this stage a slightly decreased was observed. In the case of exo-PG a similar trend was followed, being the stage of maximum activities shorter, between the $4^{\text {th }}$ and $6^{\text {th }}$ days, and reaching a peak of $79 \mathrm{IU} / \mathrm{gds}$. Many works describe this typical phenomenon of a sudden increase and subsequent decrease in enzymes activities during the cultivation period (44). One of the argued reasons is the sporulation of the strain, which reduces the enzymatic activity (4). Maybe, xylanase or exo-PG produced during the first stage of fermentation are degraded or denaturalized after onset of sporulation during days $8^{\text {th }}$ to $15^{\text {th }}$. In the case of CMCase and $\alpha$-amylase, production remained almost constant along the fifteen days of fermentation, with average values of 19 and $21.5 \mathrm{IU} / \mathrm{gds}$, respectively.

Besides, as it can be observed in Figure 2B, reducing sugars concentration also showed the two mentioned stages, measuring values about $2 \mathrm{mM}$ in the fermentations media at the $3^{\text {th }}$ day, but values as low as $0.72 \mathrm{mM}$ at the $7^{\text {th }}$ day of culture. On the other hand, the $\mathrm{pH}$ increased slightly during the fermentation up to values around 7 units, probably due to the utilization of organic acids by the fungus as carbon sources when sugars are limited (41).

These data can be considered of the same order of magnitudes or even higher than those registered in literature for other residues used as solid substrate, especially for xylanase and pectinase. Thus, Couri et al. (2000) studied the production of xylanase by Aspergillus niger 3T5B8 using two agroindustrial residues - mango peels and wheat bran- as solid substrate. For those experiments, $40 \mathrm{~g}$ of the sterile solid with a moisture level around $60 \%$ were incubated at $32{ }^{\circ} \mathrm{C}$. The maximum xylanase activity of $100 \mathrm{IU} / \mathrm{gds}$ was reached after 72 $\mathrm{h}$ of incubation by using wheat bran as solid substrate. With mango peels, a peak of activity of $50.4 \mathrm{IU} / \mathrm{gds}$ was attained after $24 \mathrm{~h}$ of fermentation (15). In the same line, the production 
of xylan degrading enzymes by $A$. Awamori has been tested by using grape pomace as solid substrate and a maximum value of $38 \mathrm{IU} / \mathrm{gds}$ was measured (11). Yang et al. (2006) cultivated Penicillium decumbens on a mixture of $90 \%$ corn straw and 10 $\%$ wheat bran, moistened with a mineral solution, and measured $13.59 \mathrm{IU} / \mathrm{gds}$ of xylanase after 4 days of culture at 28 ${ }^{\circ} \mathrm{C}$ (53). The production of xylanases by a koji mold, Aspergillus oryzae RIB 128, has also been tested on dried wheat bran, rice bran and orange peel (52). The highest productivity -about $60 \mathrm{IU} / \mathrm{gds}$ - was reached when wheat bran was used as substrate. For those experiments the moisture content of the solid was adjusted to $67 \%$, and solid state cultures were grown at $30{ }^{\circ} \mathrm{C}$ for 4 days. The production of xylanase by the bacterial strain Bacillus licheniformis has also been reported. In this case, a maximum activity of $16.8 \mathrm{IU} / \mathrm{g}$ was measured after $72 \mathrm{~h}$ of inoculating the strain on $10 \mathrm{~g}$ of wheat bran with $25 \mathrm{~mL}$ of a mineral solution, and incubated at $50^{\circ} \mathrm{C}(3)$.

In the case of exo-polygalacturonase, published data on the production of this enzyme by SSF show values between 18 IU/gds (12) up to $55 \mathrm{IU} / \mathrm{gds}$ (47), suggesting that activities reported in this work are quite high. For CMCase, activities reported in this paper are quite higher than the ones obtained when banana fruit stalk waste served as solid substrate for the bacterial strain Bacillus subtilis CBTK 106 (9.6 IU/gds) (31). In the same line, groundnut fodder supported a production of $1.36 \mathrm{IU} / \mathrm{gds}$ of CMCase by Aspergillus niger by SSF, which is also quite low compared to the ones measured in this work (13). However, when Aspergillus niger KK2 was grown on rice straw it produced $129 \mathrm{IU} / \mathrm{gds}$ (29) which is much higher than values measured here.

The amylase activity obtained was not significant compared to the ones measured on other agroindustrial residues used as solid substrates which contain starch. Thus, when Aspergillus oryzae was grown on rice bran as sole substrate, a peak of amylase (about 8,000 IU/gds) was attained after 12 hours of culture (14).

To summarize, the obtained data show that tomato pomace is a potentially promising substrate for the production of hydrolytic enzymes, particularly xylanase and exo-PG, by solid state fermentation. Considering that tomato processing industries produce annually large amounts of this residue and one of the highest production costs of microbial enzymes is the fermentation medium, obtaining xylanase or exo-PG by using this residue -or mixtures of this with others- could be a new and economic alternative.

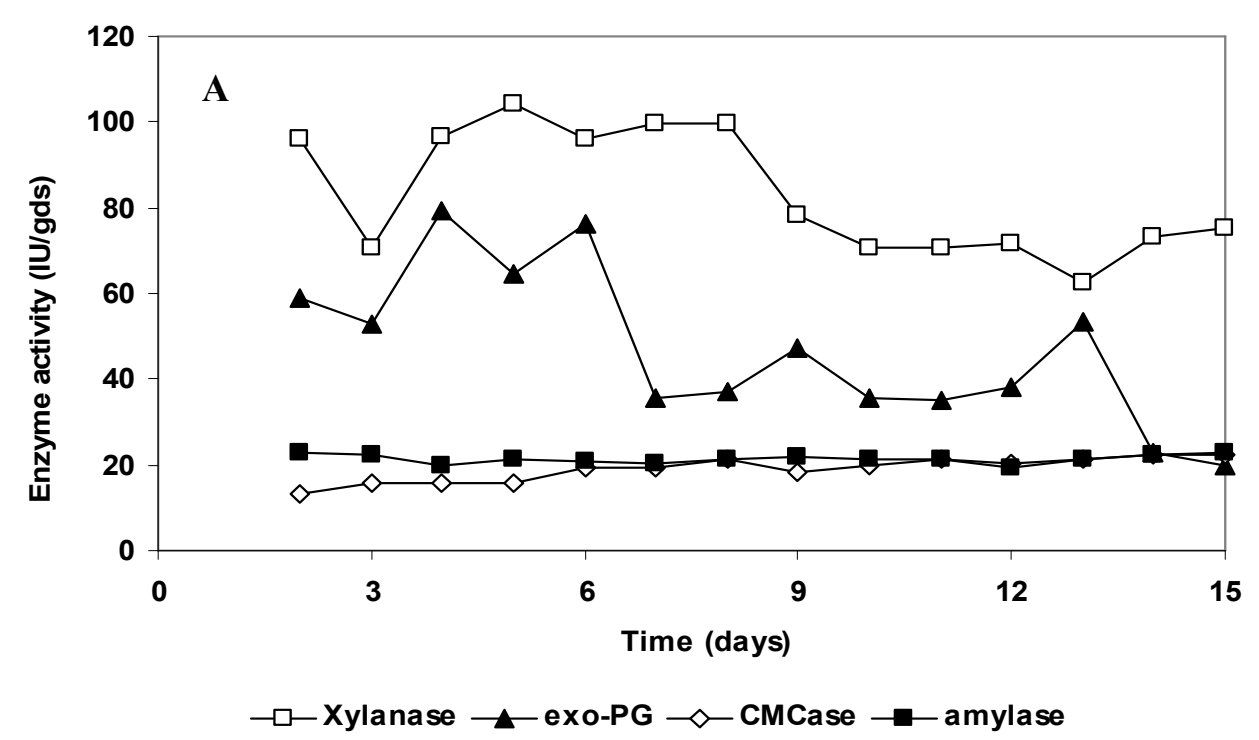




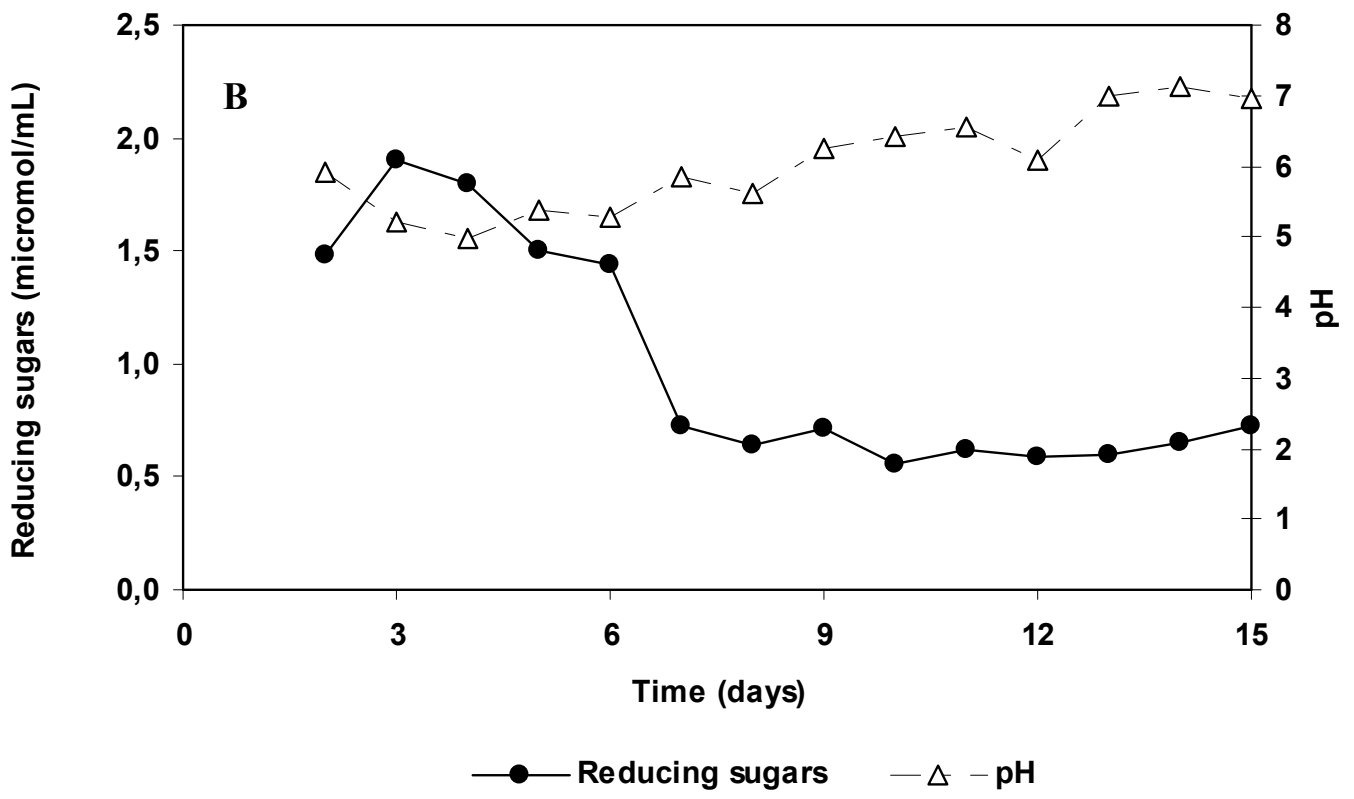

Figure 2. Enzyme activities measured in conical flasks (A). Reducing sugars concentration and $\mathrm{pH}$ along time of fermentation (B)

\section{Enzymes production in plate-type SSF reactor}

As a consequence of the results above mentioned, the production of selected enzymes was studied in a lab scale plate-type SSF bioreactor, in order to evaluate the effect of aeration during the fermentation process. This special configuration (see Figure 1) allows the distribution of the substrate along different layers with a low height of bed, which can improve mass and heat transfer and supposedly favor the fermentation process and the enzymes production.

In Table 1 are included the values obtained for the enzymatic activities measured in conical flasks and the average values within the five plates which constitute the bioreactor, for experiments with forced aeration, saturated and no saturated in water. All values were registered at the fifth day of culture, which was the day in which maximum activity of xylanase was reached. With regard to the data measured in the bioreactor, they represent the average of activities registered in the five plates because, at the conditions tested, no significant differences were observed along them. This fact could be explained considering that variables of fermentation - temperature and moisture content- were maintained almost constant in all the plates. In this sense, temperature into the air phase was kept almost constant during the five days of fermentation, around $28-29{ }^{\circ} \mathrm{C}$, and no differences between the air inlet and the air outlet were measured. Moreover, when air saturated with water was used, the air humidity was also kept invariable during the fermentation (around $93 \%$ ). However, some differences were measured when air without humidification was applied. In this case, the humidity of the air inlet was about $54 \%$ and the outlet one reached $95 \%$, showing that water molecules diffuses from the solid medium to the gas phase. Nevertheless, humidity percentages in the solids remained above $50 \%$ after 5 days of culture along the five plates in all the experiments carried out, which is enough to support the fungal growth.

As can be seen in Table 1, aeration showed a clear positive effect on xylanase and CMCase production. In case of xylanase, the employment of water saturated aeration improved productivity 1.9 times, while for no saturated air increased 1.7 times, compared to values registered in conical flask (no forced 
aeration). For CMCase, activity increased by 1.3 and 1.4 folds, with water saturated air and not humidified air, respectively. However, for exo-PG and $\alpha$-amylase aeration seemed to have a negative effect on their synthesis, reducing to half their activities. At this respect, some authors have previously reported the negative effect of aeration on the production of several enzymes. In this way, (4) concluded that forced aeration in a multi-layer packed bead reactor induced more sporulation of the fungal strain and reduced the enzymes production. Another aspect to be considered is that enzymatic activities presented in Table 1 were measured at the $5^{\text {th }}$ day of culture, when high levels of activity were measured in conical flask experiments; however, in platetype bioreactor those maximums could be reached earlier or later, depending on the particular enzyme.

Table 1. Enzyme activities measured in conical flasks and average values along the five plates which constitute the bioreactor, for experiments with forced aeration, saturated and no saturated in water. All values were registered at the fifth day of culture

\begin{tabular}{lccc}
\hline & & \multicolumn{2}{c}{ Plate-type SSF bioreactor } \\
\cline { 3 - 4 } & Conical Flask & $\begin{array}{c}\text { Water saturated forced } \\
\text { aeration }\end{array}$ & Forced aeration \\
\hline Xylanase (IU/gds) & $104.43 \pm 5.2$ & $195.92 \pm 11.0$ & $182.34 \pm 9.0$ \\
Exo-PG (IU/gds) & $64.5 \pm 8.6$ & $36.16 \pm 4.9$ & $29.04 \pm 1.7$ \\
CMCase (IU/gds) & $15.52 \pm 0.4$ & $19.71 \pm 1.5$ & $21.86 \pm 0.7$ \\
$\alpha$-amylase (IU/gds) & $21.30 \pm 0.8$ & $10.85 \pm 0.8$ & $11.05 \pm 0.6$ \\
Humidity (\%) air inlet & - & $93.60 \pm 2.2$ & $53.68 \pm 2.7$ \\
Humidity $(\%)$ air outlet & - & $93.34 \pm 3.8$ & $95.30 \pm 2.8$ \\
Temperature $\left({ }^{\circ} \mathrm{C}\right)$ air inlet & - & $28.68 \pm 0.2$ & $28.07 \pm 0.1$ \\
Temperature $\left({ }^{\circ} \mathrm{C}\right)$ air outlet & - & $28.74 \pm 0.1$ & $28.11 \pm 0.2$ \\
\hline
\end{tabular}

\section{Influence factors on xylanase activity}

As it can be seen in Figure 3A, the shape obtained for the $\mathrm{pH}$ influence shows the general behavior for this influence factor. If we adjust the data to a smooth curve, the optimum $\mathrm{pH}$ for xylanase activity was measured around $\mathrm{pH}$ 5.0. If this value is considered as $100 \%$ of activity, $99 \%$ and $97 \%$ are registered for $\mathrm{pH} 4.5$ and 3.5, respectively. At $\mathrm{pH}$ values higher than 10, no enzymatic activities were measured. This behavior is similar to the ones reported for other fungi, such as Aspergillus kawachii (28) and Penicillium herquei (25) who exhibited optimum $\mathrm{pH}$ between 2 and 6 for xylanase activity.

With regard to the influence of temperature, as it can be seen in Figure 3B, the shape obtained is also the expected. Over the smooth curve, the maximum temperature for xylanase activity was reached at $50{ }^{\circ} \mathrm{C}$ and then decreased at higher temperatures. Beg et al. (2001) assayed the optimum conditions for the activity of xylanase, produced by different fungi, and obtained that the optimum $\mathrm{pH}$ and temperatures were in the range $2-8$ and $40-75{ }^{\circ} \mathrm{C}$, respectively. Similar conclusions were reached by Kulkarni et al. (1999).

As it was stayed in the Materials and Methods section, the effect of incubation time on enzyme stability was studied by maintaining crude enzyme solution in the absence of substrate at $50{ }^{\circ} \mathrm{C}$ for 360 minutes. Periodically, an aliquot was withdrawn and assayed for residual xylanase activity. The results of this experiment were used to study the spontaneous inactivation kinetics of xylanase at optimum conditions $\left(50^{\circ} \mathrm{C}\right.$, $\mathrm{pH}$ 5.0). For this purpose, the semi-logarithmic plot of the residual activity divided by the initial one, versus time, was graphically represented. The inactivation rate constant $\left(\mathrm{k}_{\mathrm{d}}\right)$ was calculated from the slope, being $0.0136 \min ^{-1}\left(r^{2}=0.9027\right)$. This value was used to estimate the apparent half life $\left(t_{1 / 2}\right)$ of this enzymatic activity, obtaining that it is equal to 51 minutes at the experimental conditions. 
In relation with the cations influence, Table 2 shows the relative xylanase activity in presence of several salts. Among them, only $\mathrm{Mg}^{2+}$ seems to stimulated the xylanase activity, while $\mathrm{Hg}^{2+}, \mathrm{Cu}^{2+}$ and $\mathrm{Mn}^{2+}$ strongly inhibited this enzyme activity. At this respect, $\mathrm{Hg}^{2+}$ and $\mathrm{Cu}^{2+}$ have been commonly reported as inhibitors of xylanase $(7,45)$ because they can break disulfide bonds in proteins, which are covalent linkers joining the structure of the protein and play an important role in the enzyme conformation for catalytic activity $(38,50)$. Other divalent cations, as $\mathrm{Fe}^{2+} \mathrm{Ca}^{2+}$ or $\mathrm{Ba}^{2+}$, seem to inhibit this enzymatic activity in much less proportion. Finally, $\mathrm{K}^{+}$inhibits double when the cation is present in a double concentration.
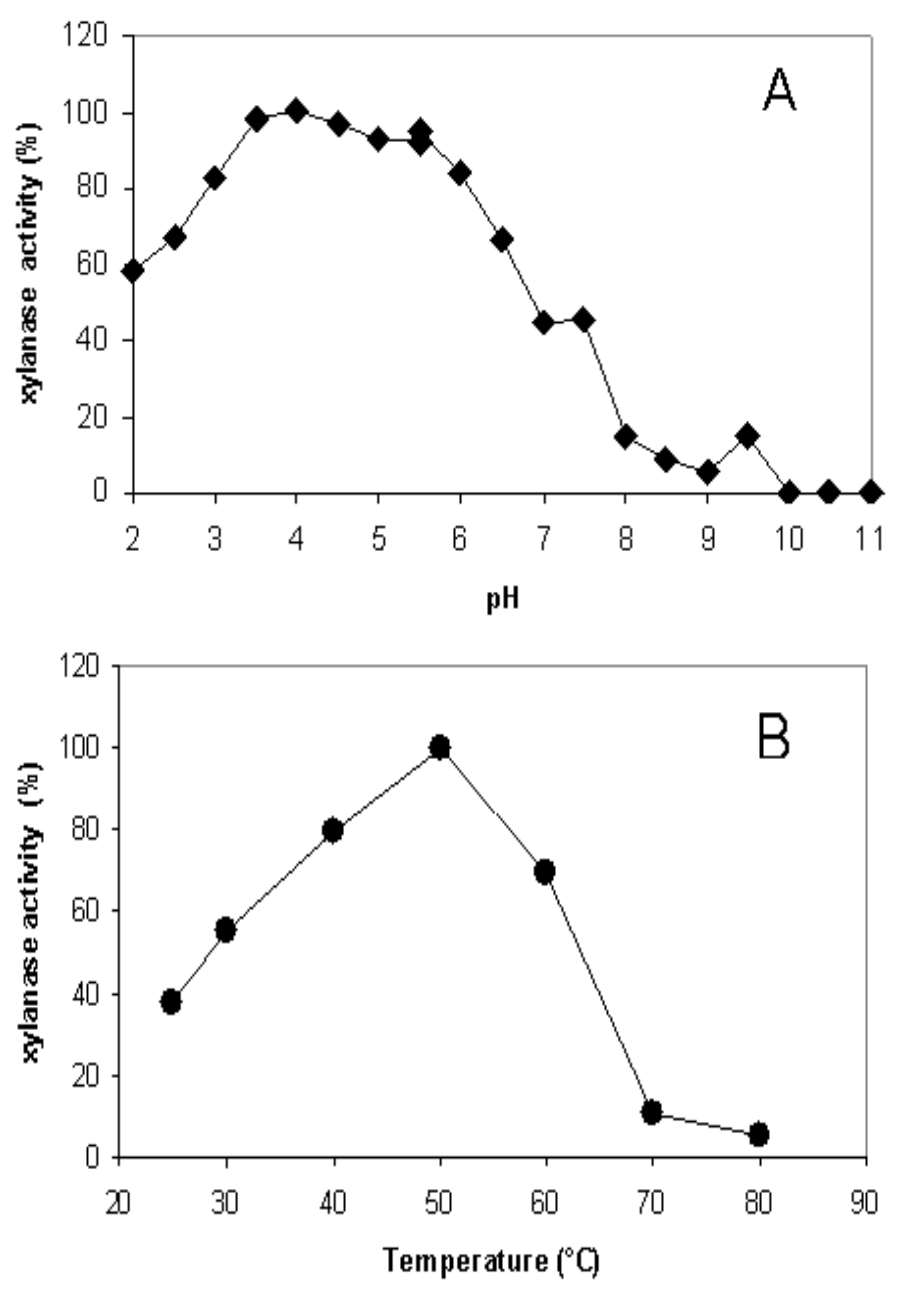

Figure 3. Optimum pH (A) and temperature (B) of xylanase activity from Aspergillus awamori on tomato pomace
Table 2. Effect of ions on xylanase activity produced by Aspergillus awamori on tomato pomace

\begin{tabular}{cc}
\hline $\begin{array}{c}\text { Salt } \\
(\mathbf{0 . 1 ~ M})\end{array}$ & $\begin{array}{c}\text { Relative activity } \\
(\%)\end{array}$ \\
\hline $\mathrm{Control}^{2+}$ & 100 \\
$\mathrm{Hg}^{2+}$ & 7.5 \\
$\mathrm{Cu}^{2+}$ & 18.9 \\
$\mathrm{~K}^{+}\left(\mathrm{SO}_{4}{ }^{-}\right)$ & 46.5 \\
$\mathrm{Mn}^{2+}$ & 54.6 \\
$\mathrm{Ba}^{2+}$ & 70.6 \\
$\mathrm{Fe}^{2+}$ & 72.5 \\
$\left(\mathrm{NH}_{4}\right)^{+}$ & 82.1 \\
$\mathrm{Ca}^{2+}$ & 82.7 \\
$\mathrm{~K}^{+}\left(\mathrm{Cl}^{-}\right)$ & 87.9 \\
$\mathrm{Mg}^{2+}$ & 111.0 \\
\hline
\end{tabular}

\section{Stability of xylanase activity}

The investigations conducted over the influence of $\mathrm{pH}$ on the enzyme stability revealed that xylanase was very stable within the $\mathrm{pH}$ range evaluated (see Figure 4A). Thus, enzymatic activity is maintained almost constant at all values tested. In consequence, the xylanase characterized in this study can be a potential candidate for different applications in the enzyme industry, demanding either acidic or alkaline $\mathrm{pH}$ ranges. Among the xylanases obtained from different microbial sources, most are inhibited at high $\mathrm{pH}$. For example, the xylanase isolated from Penicillium capsulatum was only active in the acidic $\mathrm{pH}$ range, with a rapid decline in activity above pH 5 (43). The xylanase produced by Bacillus thermoalkalophilus was stable in the $\mathrm{pH}$ range $4-6$, but the activity was progressively decreasing at $\mathrm{pH}$ values below 4 and above 6.

Finally, the results obtained in the study of the thermostability of xylanase are represented in Figure 4B. As it can be seen, xylanase actitity remained almost constant between $30{ }^{\circ} \mathrm{C}$ to $45^{\circ} \mathrm{C}$. However, it decreased to half at $50{ }^{\circ} \mathrm{C}$. A more accused diminution was produced at $60{ }^{\circ} \mathrm{C}$ and $70{ }^{\circ} \mathrm{C}$. Data reviewed (8) show that xylanase produced by different fungi are stable in the temperature range $24-60{ }^{\circ} \mathrm{C}$. Xylanase from Aspergillus kawachii IFO 438 was stable in the $\mathrm{pH}$ range $1-10$ and in the temperature range $30-60{ }^{\circ} \mathrm{C}(28)$. 

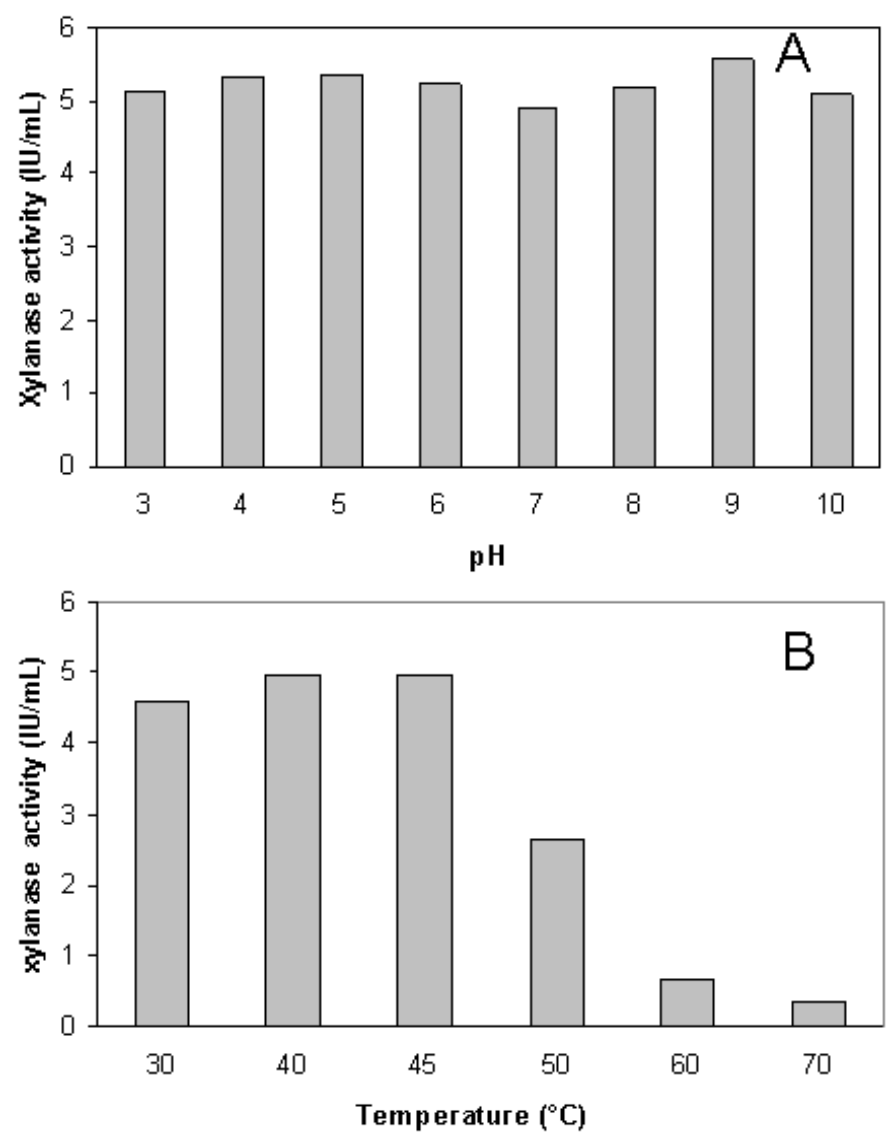

Figure. 4. Effect of $\mathrm{pH}(\mathrm{A})$ and temperature (B) on xylanase stability.

CONCLUSIONS

Tomato pomace (peel, seeds and pulp), a residue generated in large amounts by the agro-food industry, is a good natural medium for fungal growth in solid state fermentation (SSF). Its low cost makes it potentially promising raw material for the production of high added value products, such as hydrolytic enzymes. As one of the main cost in the production of industrial enzymes is the medium of fermentation, in the present work tomato pomace has been evaluated for the production of a range of hydrolytic enzymes including xylanase, exo-PG, CMCase and $\alpha$-amylase. The highest titers were measured for xylanase, being superior or of the same order of magnitude than the ones reported for other agriculture substrates and microorganisms. The production of this enzyme can be highly improved by using forced aeration in plate-type bioreactor. Xylanase has been characterized in relation to its optimum activity and stability. Results obtained indicated that xylanase produced by Aspergillus awamori on tomato pomace shows an optimum $\mathrm{pH}$ of 5 units and optimum temperature of $50{ }^{\circ} \mathrm{C}$. It is activated by $\mathrm{Mg}^{2+}$ and highly inhibited by $\mathrm{Hg}^{2+}$ and $\mathrm{Cu}^{2+}$. The enzyme remained quite active in a broad range of $\mathrm{pH}$, maintaining almost constant its activity. With regard to the stability against temperature, xylanase activity remained constant between $30{ }^{\circ} \mathrm{C}$ to $45^{\circ} \mathrm{C}$ and decreased for higher temperatures. A half-life of the enzyme activity of 51 minutes was calculated at the optimum conditions.

\section{ACKNOWLEDGEMENTS}

Brazilian authors would like to acknowledge the financial assistance provided by Fundação de Amparo a Pesquisa do Estado de São Paulo, FAPESP. Spanish authors wish to thank the Ministerio de Ciencia y Tecnología of Spain for financial support (CTQ2006-04257/PPQ).

\section{REFERENCES}

1. Acuña-Argüelles, M.E.; Gutiérres-Rojas, M.; Viniegra-González, G.; Favela-Torres, E. (1995). Production and properties of three pectinolytic activities produced by Aspergillus niger in submerged and solid-state fermentation. Appl. Microb. Biotechnol. 43: 808-814.

2. Al-Wandawi, H.; Abdul-Rahman, M.; Al-Shaikhly, K. (1985). Tomato processing waste as essential raw materials source. J. Agric. Food Chem. 33:804-807.

3. Archana, A.; Satyanarayana, T. (1997). Xylanase production by hermophilic Bacillus licheniformis A99 in solid state fermentation. Enzyme Microb. Technol. 21: 12-17.

4. Assamoi, A.; Destain, J.; Delvigne, F.; Lognay, G.; Thonart, P. (2008a). Solid-state fermentation of xylanase from Penicillium canescens 10-10c in a multi-layer-packed bed reactor. Appl. Biochem. Biotechnol. 145: 8798.

5. Assamoi, A.; Destain, J.; Thonart, P. (2008b). Xylanase production by Penicillium canescens on soya oil cake in solid-state fermentation. Appl. Biochem. Biotechnol. 145: 87-98. 
6. Badhan, A.K.; Chadha, B.S.; Kaur, J.; Saini, H.S.; Bhat, M.K. (2007). Production of multiple xylanolitic and cellulolytic enzymes by thermophilic fungus Myceliophthora sp. IMI 387099. Biores. Technol. 98: 504-510.

7. Bastawde, K.B. (1987). Studies on xylanase by Chainia sp. In: Ph.D. Thesis, Pune University, Pune India.

8. Beg, Q.K.; Kapoor, M.; Mahajan, L.; Hoondal, G.S. (2001). Microbial xylanases and their industrial applications: a review. Appl. Microb. Biotechnol. 56: 326-338.

9. Bewley, J.D.; Banik, M.; Bourgault, R.; Feurtado, J.A.; Toorop, P.; Hilhorst, H.W.M. (2000). Endo - $\beta$ - mannanase activity increases in the skin and outer pericarp of tomato fruits during ripening. J. Exp. Bot. 51:529-538.

10. Biely, P. (1985). Microbial xilanolytic systems. Trends Biotechnol. 3, 86-90.

11. Botella, C.; Díaz, A.; de Ory, I.; Webb, C.; Blandino, A. (2007). Xylanase and pectinase production by Aspergillus awamori on grape pomace in solid state fermentation. Process Biochem. 42: 98-101.

12. Castilho, L.R.; Alves, T.L.M.; Medronho, R.A. (2000). Production and extraction of pectinases obtained by solid state fermentation of agroindustrial residues with Aspergillus niger. Biores. Technol. 71: 4550.

13. Chandra, M.S.; Viswanath, B.; Reddy, B.R, (2007), Cellulolytic enzymes on lignocellulosic substrates in solid state fermentation by Aspergillus niger. Indian J. Microbiol. 47: 323-328.

14. Chutmanop, J.; Chuichulcherm, S.; Chisti, Y.; Srinophakun, P. (2008). Protease production by Aspergillus oryzae in solid-state fermentation using agroindustrial substrates. J Chem. Technol. Biotechnol. 83: 1012 1018 .

15. Couri, S.; Terzi, S.C.; Pinto, G.A.S.; Freitas, S.P.; Da Costa, A.C.A. (2000). Hydrolytic enzyme production in solid-state fermentation by Aspergillus niger 3T5B8. Process Biochem. 36: 255-261.

16. Da Silva, R.; Lago, E.S.; Merheb, C.W.; Macchione, M.M.; Park, Y.K.; Gomes, E. (2005). Production of xylanase and cmcase on solid state fermentation in different residues by Thermoascus aurantiacus miehe. Braz. J. Microbiol. 36:235-241.

17. Damiano, V.B.; Bocchini, D.A.; Gomes, E.; Da Silva, R. (2003). Application of crude xylanase from Bacillus licheniformis 77-2 to the bleaching of eucalyptus kraft pulp. World J. Microbiol. Biotechnol. 19: $139-144$.

18. Del Valle, M.; Cámara, M.; Torija, M.E. (2006). Chemical characterization of tomato pomace. J. Sci. Food Agric. 86: 1232-1236.

19. Díaz, A.B.; Caro, I.; de Ory, I.; Blandino, A. (2007). Evaluation of the conditions for the extraction of hydrolitic enzymes obtained by solid state fermentation from grape pomace. Enzyme Microb. Technol. 41: 302-306.
20. Díaz, A.B.; Ory, I.; Caro, I.; Blandino, A. (2010). Enhance hydrolytic enzymes production by Aspergillus awamori on supplemented grape pomace. Food Bioprod. Process. doi:10.1016/j.fbp.2010.12.003

21. Du, C.; Lin, S.K.C.; Koutinas, A.; Wang, R.; Dorado, P.; Webb, C, (2008). A wheat biorefining strategy based on solid-state fermentation for fermentative production of succinic acid. Biores. Technol. 99:83108315.

22. Fischer RL, Bennett AB.1991. Role of cell wall hydrolases in fruit ripening. Annual Review of Plant Physiology and Plant Molecular Biology 42, 675-703.

23. FAOSTAT - Food and Agriculture Organization of the United Nations. 2010. Tomato world production. Available at: http://faostat.fao.org/ site/567. Accessed 19 May 2010.

24. Fondevila, M.; Guada, J.A.; Gasa, J.; Castrillo, C. (1994). Tomato pomace as a protein supplement for growing lambs. Small Ruminant Res. 13: 117-126.

25. Funaguma, T.; Naito, S.; Morita, M.; Okumara, M.; Sugiura, M.; Hara, A. (1991). Purification and some properties of xylanase from Penicillium herquei Banier and Sartory. Agric. Biol. Chem. 55: 1163-1165.

26. Gross, K.C. (1984). Fractionation and partial characterization of cell walls from normal and non-ripening mutant tomato fruit. Physiol. Plant. 62: $25-32$.

27. Ismail, A.S. (1996). Utilization of orange peels for the production of multienzyme complexes by some fungal strains. Process Biochem. 31: 645-650.

28. Ito, K.; Ogassawara, J.; Sugimoto, T.; Ishikawa, T. (1992). Purification and properties of acid stable xylanases form Aspergillus kawachii. Biosci. Biotechnol. Biochem. 56: 547-550.

29. Kang, S.W.; Park, Y.S.; Lee, J.S.; Hong, S.I.; Kim, S.W. (2004). Production of cellulases and hemicellulases by Aspergillus niger KK2 from lignocellulosic biomass. Biores. Technol. 91: 153-156.

30. Koutinas, A.; Wang, R.; Webb, C. (2003). Estimation of fungal growth in complex, heterogeneous culture. Biochem. Eng. J. 14: 93-100.

31. Krishna, C. (1999). Production of bacterial cellulases by solid state bioprocessing of banana wastes. Biores. Technol. 69: 231-239.

32. Kulkarni, N.; Shendye, A.; Rao, M. (1999). Molecular and biotechnological aspect of xylanases. FEMS Microbiol. Rev. 23: 411456.

33. Lemos, J.L.S.;. Bom, E.P.S.; Santana, M.F.E.; Pereira J.N. (2000). Thermal stability of xylanases produced by Aspergillus awamori. Braz. J. Microbiol. 31:206-211.

34. Linde, G.A.; Magagnin, G.; Costa, J.A.V.; Bertolin, T.E.; Colauto, N.B. (2007). Column bioreactor use for optimization of pectinase production in solid substrate cultivation. Braz. J. Microbiol. 38:557-562.

35. Medeiros, A.B.P.; Crhisten, P.; Roussos, S.; Gern, J.C.; Soccol, C.R. (2007). Coffee residues as substrates for aroma production by 
Ceratosytis fimbriata in solid state fermentation. Braz. J. Microbiol. 34:245-248.

36. Miller, G.L. (1959). Use of dinitrosalicylic reagent for determination of reducing sugar. Anal Chem. 31: 426-428.

37. Mohana, S.; Shah, A.; Divecha, J.; Madamwar, D. (2008). Xylanase production by Burkholdery sp. DMAX strain under solid state fermentation using distillery spent wash. Biores. Technol. 99: 7553-7564.

38. Nelson, D.L.; Cox, M.M. (2002). In: Lehninger: Princípios de Bioquímica. Sarvier 3. ed. São Paulo.

39. Pandey, A. (2003). Solid-state fermentation. Biochem. Eng. 13, 81-84.

40. Patil, S.R.; Dayanand, A. (2006a). Production of pectinase from deseeded sunflower head by Aspergillus niger in submerged and solidstate conditions. Biores. Technol. 97: 2054-2058.

41. Poiana, M.; Romeo, F. (2006). Grasas y aceites 57: 402-408.

42. Rodríguez-Couto, S.; Sanromán, M.A. (2006). Application of solid-state fermentation to food industry-A review. J. Food Eng. 76: 291-302.

43. Ryan, S.; Nolan, K.; Thompson, R.; Gubitz, G.; Savage, A.; Tuohy, M. (2003). Purification and characterization of a new low molecular weight endoxylanase from Penicillium capsulatum. Enzyme Microb. Technol. 33: 775-785.

44. Shah, A.; Madamwar, D. (2005). Xylanase production by a newly isolated Aspergillus foetidus strain and its characterization. Process Biochem. 40: 1763-1771.

45. Shei, J.C.; Fratzke, A.R.; Frederick, M.M.; Frederick, J.R.; Reilly, P.J. (1985). Purification and characterization of endoxylanase from Aspergillus niger II: An enzyme of pI 4.5. Biotechnol. Bioeng. 27: 533538.

46. Shojaosadati, A.; Babaeipour, V. (2002). Citric acid production from apple pomace in multi-layer packed bed solid-state bioreactor. Process Biochem. 37: 909-914.
47. Silva, D.; Martins, E.S.; Da Silva, R.; Gomes, E. (2002). Pectinase production by Penicillium viridicatum RFC3 by solid state fermentation using agricultural wastes and agro-industrial by-products. Braz. J. Microbiol. 33: 318-324.

48. Tapingkae, W.; Yachai, M.; Visessanguan, W.; Pongtanya, P.; Pongpiachan, P. (2008). Influence of crude xylanase from Aspergillus niger FAS128 on the in vitro digestibility and production performance of piglets. Anim. Feed. Sci. Technol. 140: 125-138.

49. Tong, C.B.S.; Gross, K.C. (1988). Glycosyl-linkage composition of tomato fruit cell wall hemicellulosic fractions during ripening. Physiol. Plant. 74:365-370.

50. Vieille, C.; Zeikus, J.G. (2001). Hyperthermophilic enzymes: sources, uses and molecular mechanisms for thermostability. Microbiol. Mol. Biol. Rev. 65: 1-43.

51. Wong, K.K.Y.; Saddler, J.N. (1993). Applications of hemicelluloses in a food, feed, and pulp and paper industries. In: Hemicelluloses and Hemicellulases. Coughlan MP and Hazlewood, GP, Eds., Portland Press, London 27-43.

52. Yamane, Y.; Fujita, J.; Shimizu, R.; Hiyoshi, A.; Fukuda, H.; Kizaki, Y. (2002). Production of cellulose- and xylan-degrading enzymes by a koji mold, Aspergillus oryzae, and their contribution to the maceration of rice endosperm cell wall. J. Biosci. Bioeng. 93:9-14.

53. Yang, X.; Chen, H.; Gao, H.; Li, Z. (2001). Bioconversion of corn straw by coupling ensiling and solid-state fermentation. Biores. Technol. 78:277-280

54. Yang, S.Q.; Yan, Q.J.; Jiang, Z.Q.; Li, L.T.; Tian, H.M.; Wang, Y.Z. (2006). High level of xylanase production by the thermophilic Paecylomices themophila $\mathrm{J} 18$ on wheat straw in solid state fermentation. Biores. Technol. 97:1794-1800. 